\title{
Research on the Thermal Environment of a Traditional Folk House in the South of Hunan Province in the Summer
}

\author{
Ming-Jing $\mathrm{XIE}^{1, a,{ }^{*}}$ and Hao WANG ${ }^{1, b}$ \\ ${ }^{1}$ School of Architecture and Art, Central South University, ChangSha, \\ Hunan Province, China \\ axmj8051@163.com, b363006701@qq.com \\ ${ }^{*}$ Corresponding author
}

Keywords: Traditional folk house, the south of Hunan, transitional space, ecological experience.

\begin{abstract}
We conducted a summer thermal environment test on a traditional folk house and a modern folk house in Banliang Village, south of Hunan. The result shows that the indoor temperature of the traditional folk house is $3^{\circ} \mathrm{C}$ lower than that of the modern folk house. The temperature of the outdoor spaces, transitional spaces and bedrooms shows an obvious gradient descent. In the case that the temperature outside the wall is the same, the temperature of the inside surface of the traditional folk house's wall is $5^{\circ} \mathrm{C}$ lower than that of the modern folk house. The result indicates that the transition space of the traditional folk house is conducive to lowering the indoor temperature of the living space in summer. The thick black brick wall's insulation performance is stronger than the hollow brick wall of the modern folk house. And the southward opening of the house is conducive to enhancing the indoor natural ventilation. The ecological experience of traditional folk houses is worth learning for modern folk houses.
\end{abstract}

\section{Introduction}

Compared with the high energy consumption characteristics of modern buildings, traditional buildings in China usually use topography, built atrium, and use brick or bauxite as the wall. They often have the characteristics of warm winter, cool summer and low energy consumption. Therefore, it is necessary to passively save energy in traditional buildings. The technology is researched in order to be applied in modern architecture. In recent years, some scholars have carried out systematic thermal performance tests on the walls of traditional buildings in Beijing, and made reference for the wall selection in the area. In Hunan, tests on stone buildings in the west of Hunan province found that stone wall has good heat insulation capacity in summer, but its insulation performance in winter is not satisfactory. In the west of Sichuan province, based on the research on the different window features of traditional buildings, scholars have found that the casement window is more conducive to natural ventilation than the sliding window. The study on the traditional folk house has drawn the conclusion that the courtyard is conducive to a house's heat preservation in winter and cooling in the summer. However, the study on ecological experience of traditional folk houses in the south of Hunan has not drawn enough attention. It has affected the energy-saving design of a large number of folk houses in the south of Hunan to some extent.

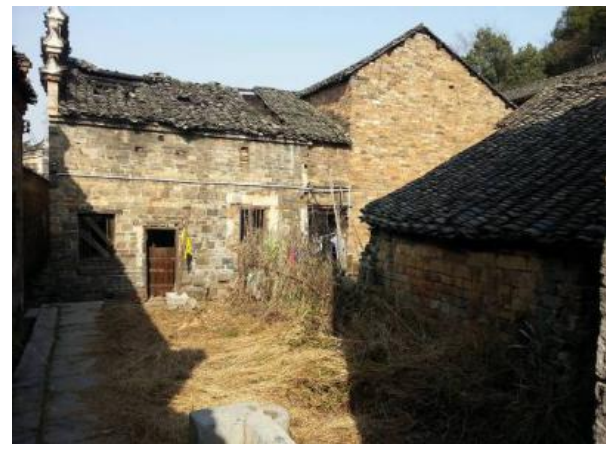

Fig. 1 The former residence of Liu Chenggao 


\section{Methodology \\ Test Object}

This paper selects Banliang Ancient Village in the south of Hunan as the test object. Banliang Ancient Village is located in Yongxing County, Chenzhou City, Hunan Province. The village locates in a typical hot summer and cold winter area. It is hot in summer, wet and cold in winter, and the temperature's diurnal range is relatively small. For the convenience of comparison, we chose the former residence of Liu Chenggao and a modern folk house in Banliang Village as test objects. The former residence of Liu Chenggao is the most representative and best preserved residential building in Banliang Village, as shown in Figure 1. Test items include temperatures of inside surfaces and outside surfaces of walls, indoor spaces' temperatures and wind speeds. The architectural and structural characteristics of the two buildings are shown in Table 1.

Table 1 structural feature of the buildings

\begin{tabular}{|c|c|c|}
\hline Object & the modern folk house & the traditional folk house \\
\hline Orientation & facing south & facing south \\
\hline $\begin{array}{l}\text { Number Of } \\
\text { Floors }\end{array}$ & one story with an attic & one story with an attic \\
\hline Floor Height & $3100 \mathrm{~mm}$ & $3300 \mathrm{~mm}$ \\
\hline Roof Material & concrete and tile & tile \\
\hline Wall Material & red brick & black brick \\
\hline \multirow[t]{2}{*}{ Wall Structure } & $\begin{array}{ll}\text { 1. lime mortar } & \text { 2. red brick }\end{array}$ & \\
\hline & $\begin{array}{l}\text { 3. air interlayer 4. cement } \\
\text { mortar } \\
\text { 5. face brick }\end{array}$ & $\begin{array}{l}\text { 1. lime mortar } \\
\text { 2. black brick }\end{array}$ \\
\hline $\begin{array}{l}\text { Window's } \\
\text { Feature }\end{array}$ & $\begin{array}{l}\text { facing east or west without } \\
\text { sunshade }\end{array}$ & facing south or north without sunshade \\
\hline Window Size & $\begin{array}{c}\text { height: } 1800 \mathrm{~mm} \\
\text { width: } 920 \mathrm{~mm}\end{array}$ & height:1800mm width:1800mm \\
\hline $\begin{array}{c}\text { Window-wall } \\
\text { Ratio }\end{array}$ & 0.25 & 0.06 \\
\hline
\end{tabular}

\section{Test Plan and Instruments}

Test parameters and instruments are shown in Table 2. The outdoor temperature is recorded by a portable weather station. It was placed on a ten meters high roof with no obstacles around. The indoor temperature is recorded by the temperature and humidity self-recording instrument. It is placed two meters high above the building and the ground. It is wrapped in aluminum foil to prevent the influence of light radiation on the measured temperature. The data is recorded every 5 minutes. The temperature of the inside and outside surfaces of the wall is measured by an infrared thermometer, and the temperature is measured every hour from 9:00 am to 9:00 pm. The test points are shown in Figure 2 and Figure 3. Before the test, we recalibrated all the test instruments, and some field instruments were re-zeroed before each test to ensure the accuracy of the test data.

\section{The Results and Analysis of the Test}

\section{Comparative Analysis of Indoor Thermal Environment of the Traditional Folk House and the Modern Folk House}

It can be considered that per unit area of the traditional folk house and the modern folk house has the same heat absorbed dose in the same time since they locate in the same area. We can analyze the 
thermal environment characteristics of the traditional folk house and the modern folk house by comparing their indoor and outdoor temperature. The measured results are shown in Figure 4. "\#” stands for the traditional folk house and “*” stands for the modern folk house. By comparing the indoor and outdoor temperatures of the two, we found that the daytime temperature is roughly in a gradient decrement following the order as outdoor - attic * - attic \# - living room * - bedroom * bedroom \#. And with the outdoor temperature lower at night, there is a gradient decrement of temperature from 3am to 5am following the order as bedroom* - living room * - attic* - bedroom\# attic\# - outdoor. The result of this change shows that outdoor temperature changes have a greater effect on the modern folk house's bedroom than that of the traditional folk house. The fluctuation range of the traditional folk house is about $7.5^{\circ} \mathrm{C}$, while that of the modern folk house is about $5^{\circ} \mathrm{C}$. And the temperature of the traditional folk house is about $3^{\circ} \mathrm{C}$ lower than the other one's during the whole test. These two points indicate that the thermal environment of the traditional folk house is better than that of the modern folk house in summer. In the respect of the external surface of the building, the difference between the two types of building thermal environment stems from two factors. Firstly, the traditional folk house's window-wall ratio is much smaller than that of the modern folk house, which means that during the day, the quantity of heat that the traditional folk house obtain through the opening of the building surface is much less than that of the modern folk house. Secondly, the traditional folk house's attic completely covers the lower-rise building, while the modern folk house's attic is not only lower than the former one's, but its horizontal area is only about one-half of the whole building's area. So, it's shading and heat insulation effects on the building is far less than the former's.

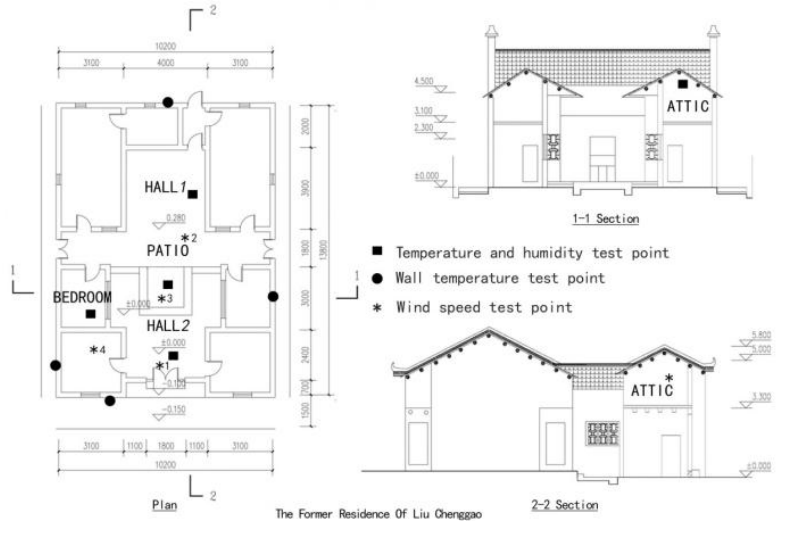

Fig. 2 Test points in the traditional folk house

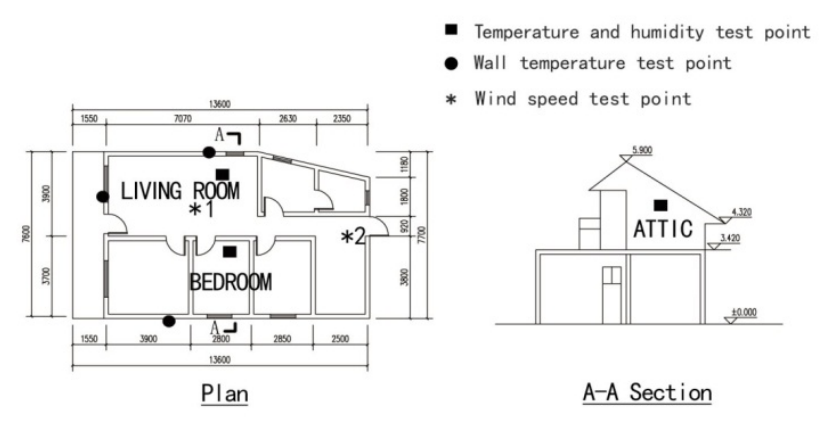

Fig. 3 Test points in the modern folk house

Table 2 Test parameters and instruments

\begin{tabular}{|c|c|c|c|c|}
\hline Test Parameters & $\begin{array}{c}\text { Test } \\
\text { Instruments }\end{array}$ & $\begin{array}{c}\text { Instrument } \\
\text { Model }\end{array}$ & Precision & $\begin{array}{l}\text { Recording } \\
\text { Method }\end{array}$ \\
\hline $\begin{array}{l}\text { Outdoor weather } \\
\text { parameters (solar } \\
\text { radiation, outdoor } \\
\text { wind direction, } \\
\text { outdoor temperature } \\
\text { and humidity) }\end{array}$ & $\begin{array}{c}\text { Portable } \\
\text { weather station }\end{array}$ & Casella NOMAD & $\begin{array}{c}\text { temperature } \pm 0.3^{\circ} \mathrm{C} \text {; } \\
\text { humidity } \pm 3 \% \text {; } \\
\text { wind speed } \pm 1 \% \text {; } \\
\text { wind direction } \pm 20 \text {; } \\
\text { sun radiation } \pm 0.1 \mathrm{~W} / \mathrm{m} 2\end{array}$ & $\begin{array}{c}\text { recording } \\
\text { automatically in } \\
\text { every } 20 \text { minutes }\end{array}$ \\
\hline $\begin{array}{l}\text { Indoor temperature } \\
\text { and humidity }\end{array}$ & $\begin{array}{l}\text { Temperature } \\
\text { and humidity } \\
\text { recorder } \\
\text { platinum } \\
\text { esistance } \\
\text { thermometer }\end{array}$ & Testo 175-H2 & $\begin{array}{l}\text { temperature } \pm 0.5^{\circ} \mathrm{C} \\
\text { humidity } \pm 3 \%\end{array}$ & $\begin{array}{c}\text { recording } \\
\text { automatically in } \\
\text { every } 5 \text { minutes } \\
\text { recording } \\
\text { automatically in } \\
\text { every } 5 \text { minutes }\end{array}$ \\
\hline
\end{tabular}




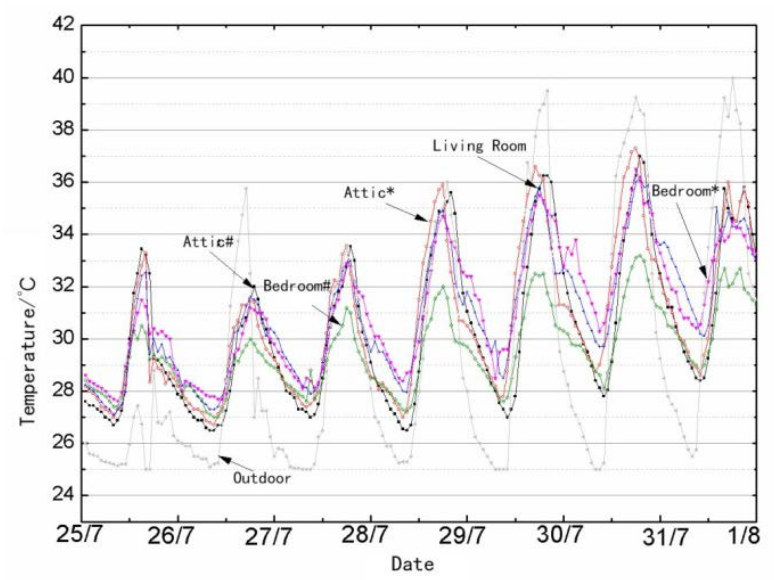

Fig. 4 Comparison of the thermal environment between the traditional folk house and the modern folk house in summer

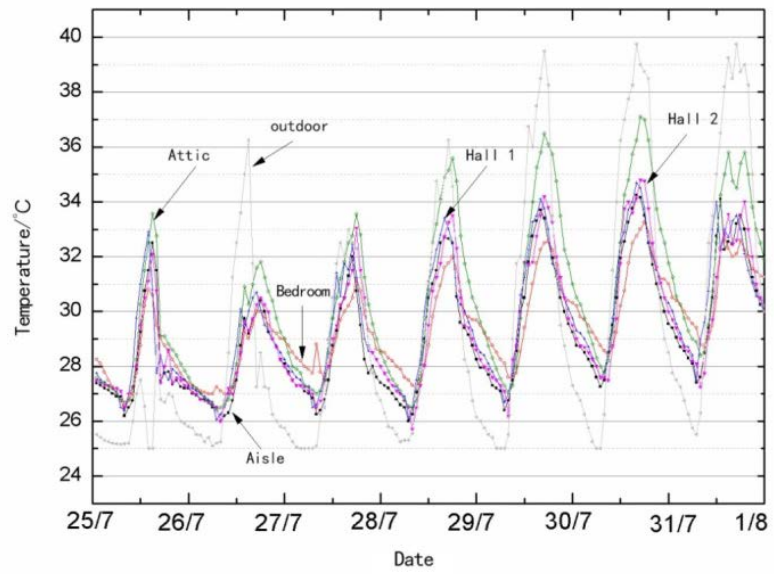

Fig. 5 Indoor temperatures of the traditional folk house

The temperature of spaces in the traditional folk house from July 25 to August 1 is shown in Figure 5. In order to find the characteristics of its interior space design, the indoor and outdoor thermal environment of the traditional building was analyzed separately. We found that the daytime temperature was roughly distributed from high to low following the order as outdoor - attic - hall 2 aisle - hall 1 - bedroom. This order is also arranged according to the opening degree of each space of the building, indicating that the higher the room's opening degree is, the greater the indoor temperature is affected by the outdoor. So the bedroom with the lowest opening degree can be $7^{\circ} \mathrm{C}$ lower than outside when it is the highest temperatures during the day. As the outdoor temperature decreases, the temperature of the attic that directly contacts the outside changes the most, and the temperature difference between day and night is as high as $9^{\circ} \mathrm{C}$, while that of the spaces such as the hall is also $7^{\circ} \mathrm{C}$. But the minimum open room's temperature difference between day and night is only $5^{\circ} \mathrm{C}$. On the basis of the fact that the opening degree has a direct influence on the indoor temperature, the analysis on the building space finds that since the attic is directly connected to the outdoor and it is subjected to the dual effects of solar radiation and the outdoor air's heat transfer, the attic's temperature is much higher than other interior spaces during the daytime. The halls and aisles are not directly in contact with the outdoors, and the patio in the middle of the building has a certain ventilation and heat dissipation, so the temperature is lower than that of the attic, but the hot air that gets in because of the high opening degree also brings a lot of heat and causes the temperature to be higher than the bedroom. When the outdoor temperature decreases at night, transition space such as the hall, the attic, and the aisle is also more susceptible to the outdoor thermal environment, resulting in a larger temperature drop.

In summary, the traditional folk house's space layout presents the characteristics that the north 
and south sides of the house are longer than the east and west side. This arrangement reduces the solar radiation to the interior of the building. The high-rise attic in the vertical space plays a good role in heat insulation and shading. Specifically, the patio in the middle of the building can bring in outdoor air to form wind pressure ventilation. And when the weather is hot, thermal pressure ventilation occurs due to the large temperature difference between indoor and outdoor. There are halls on the north and south sides of the patio, which acts as a thermal buffer for the interior of the building. The bedrooms locate outside the hall, and the heat brought by the outdoor hot air is greatly reduced by the buffer of the hall.

\section{Performance Analysis of Envelope Structure}

We analyzed the thermal insulation capacity of the traditional folk house's walls and the modern folk house's in summer by comparing the temperature changes between the inside and outside surfaces of their walls. Since the surrounding buildings of the traditional folk house and the modern folk house have different shading effects on them, and the north walls of both are back-positive, so we chose the north walls as the sample for comparative analysis. The measured north walls' data is shown in Figure 3.3. "\#” stands for the traditional folk house and "*” stands for the modern folk house. The temperature curve of the outside surface of the traditional folk house's north wall is similar to that of the modern folk house, and their temperature peaks are similar, too. But the temperature of the inside surface of the traditional folk house's north wall is significantly lower than that of the modern folk house. The gap is up to $5^{\circ} \mathrm{C}$. It indicates that the thermal insulation performance of black brick walls is better than that of hollow brick walls. In addition, the peak temperatures of the outside surfaces appear at the same time. But the peak temperature of the inside surface of the traditional folk house's wall appears one hour later than the latter's, indicating that the traditional folk house's wall is more thermally inert. The greater the thermal inertia of the folk house's envelope structure is, the more obvious the thermal delay of the wall will be. According to the formula:

$$
\text { Index of thermal inertia } \mathrm{D}=\sum \text { Thermal resistance } \times \text { Heat storage coefficient. }
$$

It can be inferred that when the thermal resistance of the empty brick wall is greater than that of the black brick wall, the heat storage of the black brick wall is greater than that of the empty brick wall. So it can be considered that the heat storage capacity rather than the thermal resistance has a greater influence on the insulation capacity of the wall.

We explored the effect of black brick walls on the heat insulation by separately analyzing the temperature of the inside and outside surfaces of the traditional folk house's wall. The result is shown in Figure 3.4. The peak temperatures of the inside surfaces of the three walls we tested appear about three hours later than the peak temperatures of the outside surfaces. It indicates that the thermal delay of the wall is very significant. Due to the influence of western exposure, the peak temperature of the outside surface of the west wall is as high as $52^{\circ} \mathrm{C}$, but the inside surface's peak temperature has been kept below $36^{\circ} \mathrm{C}$, which indicates that the black brick wall does have excellent thermal insulation properties. The south wall is obscured by adjacent buildings, and it's not affected by solar radiation. Therefore, the temperature of the south wall's outside surface is only slightly higher than the inside surface by about $2.5^{\circ} \mathrm{C}$. This proves that the low-rise and high-density architectural layout in summer plays a good role in the mutual shading between buildings. 


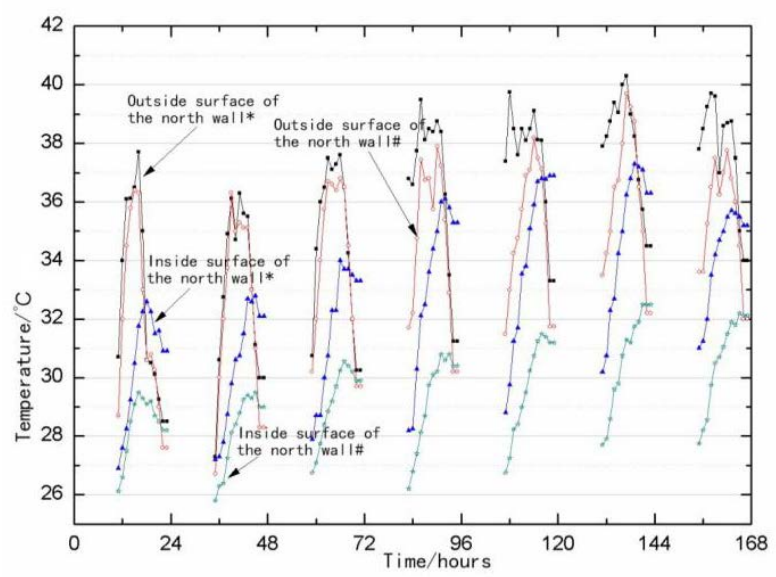

Fig. 6 Comparison of the north walls' temperatures

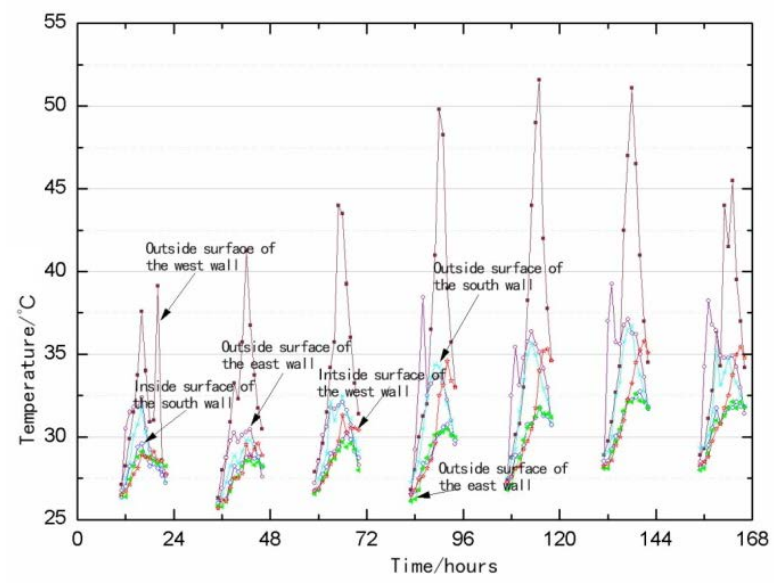

Fig. 7 Comparison of temperatures of the traditional folk house's walls

\section{Conclusion}

After field measurement and analysis, the application effect of the passive energy-saving technology of the traditional folk house has been confirmed. The design of the transition space and the low-rise and high-density architectural layout are most worth learning for modern folk houses. And a different conclusion from previous studies was obtained about the influence of the wall's structure on the indoor thermal environment: compared with the thermal resistance of the envelope structure, the heat storage capacity of the wall has a greater influence on the thermal insulation performance of the envelope structure. At the same time, there are some defects of traditional folk houses should be corrected. For example, we can adjust the openings of the folk house and adjust the patio's layout to improve the indoor lighting. Only a dialectical reference to the design of traditional folk houses can guide the application of passive energy-saving technologies' application in modern folk houses correctly.

\section{Acknowledgement}

This research was financially supported by the National Science Foundation.

\section{References}

[1] Wang Zhen. Talking about Passive Energy-saving Technology of Traditional Dwellings--Taking Hedong Village of Tuochuan Township, Wuyuan County, Shangrao City, Jiangxi Province as an Example [J]. Science and Technology of West China, 2012, (04): 43-44+22. 
[2] Nan Yanli, Zhong Huizhi. Analysis of Ventilation Effect of Different Opening Ways of Exterior Windows in Western Sichuan [J]. Shanxi Architecture, 2015, (09): 112-113.

[3] He Yuyao, Mao Guohui. Thermal Environment Analysis and Energy Saving Measures of Traditional Stone Houses in Western Hunan [J]. New Architecture, 2012, (06): 98-101.

[4] Nan Yanli, Zhong Huizhi. Analysis of Ventilation Effect of Different Opening Ways of Exterior Windows in Western Sichuan [J]. Shanxi Architecture, 2015, (09): 112-113.

[5] Tang Li, Pei Jingyang, Liu Ruoyu. Preliminary Study on Energy-saving Technology of Traditional Residential Houses in Henan Province in Henan Province [J]. Building Science, 2012, (06): 10-13+23.

[6] Chen Ping, Huang Zhuangwei. Analysis of Energy-saving Structures of Traditional Residential Buildings in Xiamen Area [J]. Shanxi Architecture, 2011, (27): 194-196. 